\title{
ASPEK FISIOLOGIS DAN BIOKIMIAWI INFEKSI JAMUR PATOGEN TUMBUHAN
}

\begin{abstract}
Abdul Gafur ${ }^{1}$
ABSTRACT

Physiological and biochemical aspects of plant fungal pathogen infections. Interaction between plants and pathogens is a major subject of interest in the field of contemporary plant pathology. Specificity of this kind of interaction is a very comprehensive phenomenon involving complicated mechanisms at different levels. Elucidation of this phenomenon including physiological and biochemical aspects is therefore an important task. From this point of view, enzymes play one of the most important roles in the infection process and pathogenesis. Our current understanding in this area is quite limited. A relatively limited number of enzymes have so far been studied in relation to the infection process and pathogenesis in plants. In this review, ivolvement of the enzymes, i. e. cutinases, esterases, hydrolases, lyases, cellulases, depolymerases and proteases, during the pathogenesis and their role in different stages of disease development is analyzed.
\end{abstract}

Key words: biochemistry, host - pathogen interaction, infection process, pathogenesis, physiology

\section{PENDAHULUAN}

Walaupun dianggap tidak memiliki sistem kekebalan sebagaimana halnya hewan, tumbuhan telah berevolusi untuk melengkapi diri dengan mekanisme pertahanan lain yang juga efektif dan berspektrum luas (Dangl \& Holub, 1997). Tumbuhan berbunga pada umumnya tahan terhadap sebagian besar patogen. Hanya sedikit saja interaksi tumbuhan - mikroba terjadi, yaitu tumbuhan merupakan inang yang rentan dan mikrobanya sebagai patogen yang virulen, sehingga proses infeksi yang diikuti oleh patogenesis dapat berlangsung (Ebel \& Scheel, 1997; Lebeda dkk., 1999). Karena itu, bila tumbuhan dan mikroba bertemu di habitat alam, penyakit lebih merupakan perkecualian daripada kelaziman (Dangl \& Holub, 1997).

Kekhususan (specificity) dianggap sebagai istilah paling umum untuk menggambarkan interaksi antara tumbuhan dan patogen (Lebeda, 1984). Kekhususan merupakan fenomena yang kompleks dengan hirarki yang rumit pada level berbeda dari organisasi biologis. Penguakan tentang masalah ini, termasuk di dalamnya perubahan metabolik yang terjadi pada tumbuhan selama proses patogenesis, merupakan salah satu tugas penting dalam ilmu penyakit tumbuhan masa kini (Somssich \& Hahlbrock, 1998). Pada telaah ini, hubungan antara tumbuhan dan jamur patogen diuraikan pada level fisiologis dan biokimiawi, dengan penekanan pada peran enzim selama fase-fase awal proses infeksi dan patogenesis.

\section{MEKANISME UMUM PENETRASI DAN INFEKSI JAMUR}

Salah satu langkah penting yang harus dilalui agar parasitisme dapat berlangsung adalah penetrasi parasit ke dalam jaringan tumbuhan inang. Pada infeksi oleh virus dan bakteri, proses ini bersifat pasif dan tidak diikuti oleh pembentukan struktur infeksi khusus (Agrios, 1997). Sebaliknya, jamur patogen mengembangkan struktur infeksi khusus untuk memasuki tumbuhan inang (Mendgen \& Deising, 1993; Struck dkk., 1998). Struktur infeksi dibentuk agar jamur dapat melakukan penetrasi terhadap organ, jaringan, sel dan komponen sel yang berbeda dari tumbuhan. Jamur parasit tumbuhan mengembangkan mekanisme yang berbeda untuk tujuan berbeda pula seperti misalnya untuk menginvasi tumbuhan inang, mendapatkan nutrisi dan untuk mengkoloni jaringan yang telah diinfeksinya. Pada umumnya dikenal paling tidak tiga kelompok dan/atau strategi jamur dalam hubungannya dengan interaksi dengan tumbuhan inang ini (Hahn dkk., 1997). Dalam interaksi yang sesuai (compatible), jamur nekrotrof secara cepat membunuh sel-sel inang dengan racun dan/atau enzim penghancur dinding sel (EPDS), kemudian mereka mengambil nutrisi dari sel yang telah mati. Sebaliknya, selama fase-fase awal patogenesis, jamur parasit biotrof mempertahankan integritas sel dan jaringan inang, dan mereka menyerap nutrisi dari sel inang yang masih hidup. Dia antara kedua kelompok tersebut terdapat 
kelompok jamur hemibiotrof yang dicirikan oleh fase awal biotrof dan kemudian diikuti fase nekrotrof.

Seperti telah disebutkan, proses infeksi jamur sudah tentu sangat rumit. Ada beberapa langkah, baik eksternal maupun internal, yang harus dilalui sebelum akhirnya infeksi dan patogenesis dapat berlangsung. Langkah-langkah dimaksud dapat diurutkan secara singkat sebagai berikut. Adhesi spora dan hifa ke permukaan tumbuhan, perkecambahan spora, pembentukan appresoria dan hifa penetrasi, pembentukan struktur infeksi primer, pengenalan (recognition) dan pensinyalan (signalling), pengembangan hifa infeksi dan haustoria dalam jaringan inang, serta patogenesis dan kolonisasi (Carroll \& Tudzynski, 1997). Struktur infeksi biasanya mempunyai keragaman yang besar antarkelompok taksonomik jamur yang berbeda. Ini sering dihubungkan dengan kekhususannya dengan jaringan tumbuhan inang dan/atau nutrisi yang dibutuhkan patogen (Mendgen dan Deising, 1993).

\section{ADHESI JAMUR}

Adhesi pada permukaan tumbuhan dianggap sebagai langkah prainfeksi yang penting (Nicholson, 1996) yang akan menentukan keberhasilan proses infeksi selanjutnya. Namun, aspek yang terlibat dalam penentuan kehususan inang - parasit ini masih belum banyak ditelaah (Carver dkk., 1996). Variasi yang luar biasa dari komposisi kimiawi permukaan tumbuhan dalam spesies yang berbeda maupun organ berbeda dari spesies tumbuhan yang sama sudah diketahui. Keberagaman ini juga telah dilaporkan sebagai ikut bertanggung jawab terhadap variasi yang besar dalam komposisi kimiawi dari senyawa adhesi jamur. Namun, hanya sedikit informasi yang tersedia tentang struktur adhesi jamur (Epstein \& Nicholson, 1997), sebagaimana juga pengetahuan tentang mekanisme adhesi yang telah diketahui (Mendgen \& Deising, 1993).

Proses adhesi jamur dipengaruhi oleh bahan ekstraseluler dengan struktur kimiawi yang sangat rumit. Bahan tersebut membentuk lapisan pada permukaan spora, dan sangat sering memiliki karakter seperti perekat. Lapisan perekat ini bisa dideteksi dengan mikroskop (Mims \& Richardson, 1989). Selain diasosiasikan dengan adhesi, lapisan perekat sering juga dianggap memiliki fungsi yang lain semisal mempertahankan kelangsungan hidup spora. Penyusun bahan adhesi jamur diperkirakan berupa polisakarida, protein serta glikoprotein dan/atau enzim
(Nicholson, 1996). Keberadaan senyawa protein dapat melindungi spora dari pengaruh metabolit sekunder inang yang beracun atau beberapa penghambat perkecambahan (Epstein \& Nicholson, 1997). Adanya interaksi hidrofobik antara spora dan kutikula tumbuhan telah dilaporkan. Pada adhesi seperti ini, hidrofobik, yakni protein yang kaya sistein, pada permukaan jamur dianggap mempunyai peran penting (Templeton dkk., 1994). Istilah adhesi juga telah diperkenalkan untuk menerangkan proses adhesi khusus yang lain walaupun latar belakang dari fenomena ini belum diketahui. Jadi jelas, sampai saat ini belum ada bukti tentang adanya senyawa adhesi ataupun mekanisme penempelan yang berlaku secara umum (Dean, 1997).

Namun, pada tahap awal proses infeksi, kehadiran beberapa enzim disepakati merupakan hal penting demi persiapan penetrasi ke pemukaan inang. Pada lapisan perekat dari spora dan kecambah beberapa spesies jamur patogen yang berbeda, ditemukan beberapa enzim seperti selulase, kutinase, DNase, esterase, invertase, pektinesterase, pektinliase, peroksidase, poligalakturonase dan protease (Mendgen \& Deising, 1993). Keterlibatan kutinase, dan sangat mungkin juga esterase, dalam pemantapan konidia Erysiphe graminis pada permukaan tumbuhan inang memang telah dibuktikan (Pascholati dkk., 1993).

\section{PERKECAMBAHAN JAMUR DAN PENGHANCURAN KUTIKULA TUMBUHAN}

Sesudah mantap pada permukaan tumbuhan, spora kemudian berkecambah. Saat pekecambahan merupakan faktor yang penting bagi kelangsungan hidup spora (Hahn dkk., 1997). Inisiasi dari proses ini dikendalikan oleh banyak faktor fisik dan kimiawi yang berbeda. Dalam hal saat perkecambahan, penghambatan diri perkecambahan memegang peran penting. Namun demikian, mekanisme dari aksi penghambatan diri ini belum dapat diterangkan secara memuaskan (Staples \& Hoch, 1997). Dalam kasus patogen penyakit karat, misalnya, turunan beberapa asam tertentu dianggap sebagai penghambat diri perkecambahan (Macko, 1981). Sebaliknya, beberapa senyawa tumbuhan yang mudah menguap (misalnya etilen) dapat menjadi pemicu perkecambahan spora.

Sitologi dari tabung kecambah telah digambarkan secara detail oleh Mendgen dan Deising (1993). Sesudah perkecambahan, tabung kecambah 
Tabel 1. Beberapa spesies cendawan patogenik yang diketahui menghasilkan kutinase pada saat proses infeksi (dimodifikasi dari Köller (1991))

\begin{tabular}{ll}
\hline Spesies cendawan & Spesies cendawan \\
\hline Alternaria alternata & Fusarium solani f. sp. phaseoli \\
Botrytis cinerea & Fusarium solani f. sp. pisi \\
Colletotrichum gleosporioides & Pythium aphanidermatum \\
Colletotrichum graminicola & Pythium ultimum \\
Gloeocercospora sorghi & Rhizoctonia solani \\
Helminthosporium carbonum & Sclerotium rolfsii \\
Helminthosporium maydis & Venturia inaequalis \\
\hline
\end{tabular}

ternyata menempel sangat kuat pada permukaan jaringan tumbuhan. Beberapa bahan kimiawi seperti protein ekstraseluler, glikoprotein dan $\beta$-1,3-glukanase terlibat dalam proses penempelan tabung kecambah ini (Hahn dkk., 1997). Tabung kecambah juga menghasilkan berbagai macam enzim penghancur kutikula dan dinding sel. Kutinase dianggap salah satu enzim yang paling penting bagi perkembangan jamur pada tahap ini, terutama untuk menembus kutikula agar penetrasi langsung jaringan tumbuhan dapat berhasil (Mendgen \& Deising, 1993). Seperti telah dipahami, beberapa spesies jamur, semisal patogen karat dan bulai, dapat juga masuk ke dalam tumbuhan secara tidak langsung melalui lubang alami ataupun luka (Howard, 1997; Lebeda \& Schwinn, 1994).

Apresoria dibentuk pada ujung tabung kecambah sebagai organ untuk menyangga hifa penetrasi. Masih sedikit informasi tentang fungsi sebenarnya dari apresoria ini (Dean, 1997). Apresoria menempel secara kuat pada substrat alami semisal epidermis daun maupun bahan buatan (Mendgen \& Deising, 1993) dan berfungsi sebagai alat bagi jamur patogen untuk memasuki jaringan tumbuhan inang (Dean, 1997). Sering kali hifa penetrasi, yang terutama bertanggung jawab terhadap penetrasi, tumbuh dari apresoria. Untuk penetrasi langsung (melalui epidermis dan rizodermis), tenaga mekanik dan kimiawilah yang berperan. Pada beberapa jamur seperti Colletotrichum dan Magnaporthe, melanin ikut membantu penetrasi. Pada spesies tertentu, apresoria yang tidak terpigmentasi tidak dapat berfungsi (Dean, 1997). Hanya apresoria yang terpigmentasi yang dapat menghasilkan tekanan osmotik yang sangat tinggi (Howard, 1997; Kubo \& Furusawa, 1991). Lapisan melanin dapat menurunkan permeabilitas dinding sel dan ini menjadi alasan mengapa jamur dapat meningkatkan tekanan turgor internal dengan menghasilkan gliserol dalam jumlah yang banyak (De Jong dkk., 1997). Namun demikian, sampai saat ini penetrasi tetap dianggap sebagai hal yang rumit dan peran enzim, terutama EPDS, tidak dapat dikesampingkan (Dean, 1997).

Permukaan tumbuhan ditutupi oleh lapisan lilin (Post-Beittenmiller, 1996). Lilin kutikula mewakili daerah pertemuan yang penting antara tumbuhan dan lingkungannya, termasuk jamur patogen. Dalam beberapa interaksi inang - patogen, ketebalan kutikula dan jumlah lilin berkorelasi secara positif dengan ketahanan tumbuhan. Namun demikian, komposisi kimiawi lilin sangat beragam dan sejauh ini belum diketahui komponennya yang bertanggung jawab terhadap interaksi inang - patogen tersebut (Jenks \& Ashworth, 1999). Bukti ilmiah tentang proses penghancuran lapisan lilin kutikula juga belum banyak. Pada penetrasi dinding sel, kutinase yang dihasilkan oleh beberapa spesies jamur (Tabel 1) mungkin memainkan peran paling penting selama fase-fase awal proses infeksi (Kolattukudy \& Crawford, 1987; Köller, 1991; Mendgen dan Deising, 1993). Telaah tentang interaksi antara Pyrenopeziza brassicae dan Brassica spp. yang dilakukan Ashby (1997) menunjukkan bahwa kutinase terlibat dalam penetrasi patogen ke dalam inangnya. Jenks dan Ashworth (1999) juga menyimpulkan bahwa produk dari gen kutinase meningkat karena adanya kontak dengan kutikula tumbuhan. Pada sisi lain, akhir-akhir ini juga 
Tabel 2. Beberapa enzim penghancur dinding sel (EPDS) yang dihasilkan cendawan patogen (dimodifikasi dari De Lorenzo dkk. (1997) dan Hahn dkk. (1997))

\begin{tabular}{ll}
\hline Kelompok enzim & Contoh enzim \\
\hline Hidrolase & endopoligalakturonase, eksopoligalakturonase, ramnogalakturonase \\
Liase & endopektat liase, eksopektat liase, endopektin liase, eksopektin liase \\
Esterase & pektinmetilesterase \\
Selulase & endo- $\beta-1,4$-glukanase (karboksimetilselulase), ekso- $\beta$-1,4-glukanase, endo- $\beta$-1,4- \\
& glukan sellobiohidrolase, $\beta$-glukosidase \\
Depolimerase & endo- $\alpha$-1,5-arabinose, $\alpha$-L-arabinofuranosidase, endo- $\beta$-1,4-silanase, $\beta$-silosidase, \\
& endo- $\beta$-glukosidase, ekso- $\beta$-1,3-glukanase (laminarinase), ekso- $\beta-1,3-1,6-$ \\
& glukanase (sinereanase), ekso- $\beta$-1,6-glukanase, $\beta$-1,4-galaktanase, \\
& $\alpha$-galaktrosidase \\
\hline & \\
\hline
\end{tabular}

diketahui bahwa beberapa kutinase hanya berperan dalam fase saprofitik saja (Köller dkk., 1995). Jadi, fungsi kutinase masih belum diketahui secara detail, dan sebagian laporan mengenai peran enzim ini pada tahap awal penetrasi masih mengandung kontroversi (Howard, 1997; Valent, 1997).

Pada jamur biotrof seperti karat dan bulai pembentukan apresoria dan penetrasi diikuti oleh sekresi enzim hidrolitik (Aist \& Bushnell, 1991; Vidhyasekaran, 1997). Bukti tentang adanya sekresi protease dan selulase dari kecambah Uromyces viciaefabae telah dikemukakan oleh Deising dkk. (1996). Namun demikian, data tentang proses enzimatik selama tahap-tahap awal infeksi pada beberapa kelompok jamur biotrof yang lain (seperti Oomycota, Peronosporales) masih belum tersedia (Lebeda \& Schwinn, 1994; Lucas dkk., 1995).

\section{PENETRASI JAMUR DAN PERUSAKAN DINDING SEL TUMBUHAN}

Menyusul keberhasilan proses adhesi spora, perkecambahan spora dan pembentukan apresoria, hifa penetrasi kemudian terbentuk. Selama proses tersebut, jamur secara intensif menghasilkan berbagai enzim penghancur. Yang terutama berperan penting dalam proses penghancuran dinding sel adalah enzim hidrolitik atau enzim litik lainnya. Menurut Agrios (1997), terdapat bukti ilmiah yang kuat dari adanya korelasi antara aktifitas EPDS, proses infeksi, patogenesis dan perkembangan gejala penyakit dalam interaksi inang - patogen yang sesuai.
Keutuhan sel tumbuhan sangat bergantung atas dinding sel yang sekaligus merupakan penghalang paling penting terhadap penetrasi langsung jamur. Dinding sel merupakan formasi yang sangat rumit dengan struktur dan komposisi yang bervariasi. Sampai saat ini, struktur dan komposisi tersebut belum diketahui sepenuhnya (Smart, 1991). Yang sudah dilaporkan adalah bahwa sel tumbuhan telah mengetahui kehadiran jamur sebelum proses penetrasi, misalnya pada proses pengenalan (Kobayashi dkk., 1992). Sel inang yang sesuai umumnya membentuk agregasi sitoplasma (Aist dan Bushnell, 1991) yang mungkin bisa dihubungkan dengan kerusakan membrannya (Mansfield dkk., 1997). Respon berupa reaksi hipersensitif (RH) ini telah diuraikan secara detail oleh Goodman dan Novacky (1994) dan Kombrink \& Somssich (1995).

Data tentang telaah mendetail tentang produksi EPDS selama pembentukan struktur infeksi jamur masih terbatas (Mendgen \& Deising, 1993). Perkembangan terakhir dari bidang ini telah disampaikan oleh De Lorenzo dkk. (1997) dan tipe EPDS yang diketahui dihasilkan oleh jamur disuguhkan di Tabel 2. Penyebaran EPDS diketahui sangat luas di antara spesies jamur walaupun EPDS yang diperlukan untuk menghancurkan polisakarida dinding sel tumbuhan dihasilkan terutama oleh jamur nekrotrof dan hemibiotrof. Hanya sedikit informasi EPDS yang diketahui disintesis oleh jamur biotrof seperti Oomycetes (Govers dkk., 1997; Kohmoto dkk., 1995). Dengan demikian, sangat sulit untuk menerangkan peran masing-masing EPDS dalam 
proses penghancuran dinding sel. Penetrasi merupakan kerjasama yang rumit dari semua EPDS yang dimiliki jamur (Mendgen dkk., 1996). Ketiadaan salah satu enzim dapat digantikan oelh enzim lain dengan kekhususan yang hampir sama (Hahn dkk., 1997).

Karena protein merupakan komponen utama dari dindng sel tumbuhan, maka enzim-enzim pektin (hidrolase, liase dan esterase), dapat dianggap sebagai salah satu kelopmpok enzin paling penting dari jamur patogenik. Pada umumnya setiap enzim, termasuk pektin, berperan dalam fase infeksi tertentu. Aksi dari hidrolase, misalnya endopoligalakturonase, merupakan prasyarat dari penghancuran dinding sel oleh enzim lain seperti pektin liase. Walaupun peran kelompok enzim pektin dalam patogenesis belum diketahui secara pasti, namun enzim-enzim tersebut telah dihubungkan dengan pilihan inang dan kekhususan genotipe patogen dan inang. Endopoligalakturonase juga diduga berperan dalam penghancuran sel, selain bertindak sebagai elisitor reaksi pertahanan tumbuhan (De Lorenzo dkk., 1997).

Selulose merupakan bahan dinding sel yang paling dominan yang terkumpul dalam bentuk mikrofibril (Smart, 1991). Enzim-enzim selulase diperlukan demi depolimerisasi dari selulose. Enzim ini diproduksi terutama oleh jamur patogen nekrotrofik (Hahn dkk., 1997). Dari telaah molekuler telah diketahui keberadaan beberapa gen yang mengendalikan produksi enzim tersebut (De Lorenzo dkk., 1997).

Depolimerase mewakili kelompok enzim yang sangat besar yang mungkin memiliki bermacammacam fungsi dalam proses infeksi dan patogenesis. Namun demikian, sebagian besar enzim ini tidak menyebabkan perubahan yang berarti pada dinding sel (De Lorenzo dkk., 1997). Hal ini ditunjukkan oleh Hahn dkk. (1997) pada interaksi antara bibit gandum dan Rhizoctonia cereali. Silanase merupakan enzim yang paling banyak ditemui dari kelompok ini pada jamur patogen rumputan. Sintesis dan sekresi silanase dalam jamur ini dirangsang oleh silan yang terdapat pada dinding sel tumbuhan inang (Hahn dkk., 1997).

Fungsi enzim protease dalam penghancuran dinding sel belum diketahui secara pasti. Namun target enzim tersebut umumnya berupa protein serat (Hahn dkk., 1997). Seperti halnya selulase, protease merupakan bagian dari EPDS pertama yang disintesis setelah pembentukan apresoria (Deising dkk., 1995; Mendgen dkk., 1996). Protease ekstraseluler telah diketahui perannya dalam patogenesis Pyrenopeziza brassicae pada Brassica spp. (Ashby, 1997). Mutan dari jamur dimaksud yang tidak dapat memproduksi protease menjadi tidak virulen. Hal ini menunjukkan bahwa protease merupakan penentu patogenesitas, walaupun kemungkinan lain seperti adanya keterpautan antara gen protease dan gen patogenesitas juga bisa terjadi.

\section{TANGGAPAN SITOLOGIS TUMBUHAN INANG TERHADAP INFEKSI PATOGEN}

Berbeda dengan jamur nekrotrof yang mempunyai kecenderungan membunuh sel inang dengan bermacam racun dan/atau enzim, patogen biotrof dan hemibiotrof menginvasi sel hidup, dan kemudian mengubah metabolisme inang demi keuntungan reproduksi dan pertumbuhan mereka. Selanjutnya sel inang yang terinfeksi mengalami beberapa perubahan seperti jumlah, bentuk, posisi dan fungsi organel sel (Šutić \& Sinclair, 1991).

Sitoskeleton terlibat dalam banyak fungsi seluler, mulai dari bentuk dan struktur sel sampai pada kematian sel terprogram (programmed cell death). Dalam kaitannya dengan infeksi patogen, alterasi sitoskeleton inang sangat penting untuk menjembatani penempelan patogen, invasi dan perkembangan struktur infeksi jamur biotrof. Beberapa jamur patogen telah berevolusi sehingga mempunyai kemampuan merusak sitoskeleton tumbuhan inang. Sejumlah elemen sitoskeleton juga diduga terlibat dalam penumpukan senyawa fenol dan karena itu juga berperan dalam mekanisme pertahanan struktural tumbuhan walaupun data rinci yang mendukung pernyataan ini belum ada (Kobayashi dkk., 1994; Heath, 1998).

\section{SIMPULAN}

Pada patosistem pertanian atau alami, tumbuhan terbuka terhadap interaksi dengan berbagai mikroorganisme, termasuk jamur. Walaupun terdapat banyak macam hubungan yang berbeda antara tumbuhan dan jamur, hanya sedikit dari interaksi ini yang menghasilkan patogenesis dan perkembangan penyakit. Kelompok terbesar dari patogen tumbuhan adalah jamur yang mewakili kelompok organisme yang sangat bervariasi. Jamur patogen hampir selalu menunjukkan kekhususan inang yang sangat tinggi. Jamur patogen juga mengembangkan strategi dan 
mekanisme yang sangat beragam agar dapat melakukan penempelan spora, invasi serta kolonisasi jaringan dan organ tumbuhan dengan baik.

Dalam patogenesis jamur, enzim memainkan peran yang sangat penting. Mereka terlibat dalam interaksi eksternal dan internal. Pada interaksi eksternal, selama proses penempelan dan perkecambahan spora, berbagai enzim (kutinase, esterase) dilepaskan pada saat yang tepat. Mereka bertanggung jawab terhadap penetrasi dinding sel epidermis dan kutikula. Proses penetrasi dinding sel dan kolonisasi jaringan inang merupakan kerjasama dari banyak enzim (enzim pektin, selulase, depolimerase, protease). Dari hubungan yang rumit itu, pengetahuan tentang peran masing-masing enzim dalam patogenesis sampai saat ini belum sepenuhnya diketahui. Telaah tentang aspek fisiologis dan biokimiawi dari proses infeksi oleh beberapa kelompok jamur, misalnya Oomycota, bahkan belum dilakukan dan karena itu perlu diupayakan.

\section{SANWACANA}

Penulis menyampaikan ucapan terima kasih kepada The Alexander von Humboldt Foundation, Bonn, Jerman, atas dukungan finansial yang diberikan kepada penulis sebagai peneliti tamu di Universitas Goettingen, Goettingen, Jerman, ketika tulisan ini diselesaikan.

\section{DAFTAR PUSTAKA}

Agrios, G. 1997. Plant Pathology. $4^{\text {th }}$ ed. Academic Press, San Diego \& London.

Aist, J.R \& W.R. Bushnell. 1991. Invasion of plants by powdery mildew fungi, and cellular mechanisms of resistance. Halaman 321-346 dalam: Cole, G.T. \& H.C. Hoch, eds. The Fungal Spore and Disease Initiation in Plants and Animals. Plenum Press, New York \& London.

Ashby, A.M. 1997. A molecular view through the looking glass: the Pyrenopeziza brassicae Brassica interaction. Adv. Bot. Res. Incorp. Adv. Plant Pathol. 24: 32-70.

Carroll, G.C. \& P. Tudzynski. 1997. The Mycota, Vol. V: Plant Relationship, Part A. SpringerVerlag, Berlin, Heidelberg \& New York.
Carver, T.L.W., S.M. Ingerson \& B.J. Thomas. 1996. Influences of host surface features on development of Erysiphe graminis and Erysiphe pisi. Halaman 255-266 dalam: Kerstiens, G., ed. Plant Cuticles - An Integrated Functional Approach. Bios Scientific Publishers, Oxford.

Dangl, J. \& E. Holub. 1997. La dolce vita: A molecular feast in plant - pathogen interactions. Cell 91: 17-24.

Dean, R.A. 1997. Signal pathways and appresorium morphogenesis. Annu. Rev. Phytopathol. 35: 211-234.

Deising, H., A.K. Frittrang, S. Kunz \& K. Mendgen. 1995. Regulation of pectin methylesterase and polygalacturonate lyase activity during differentiation of infection structures in Uromyces viciae-fabae. Microbiology 141: 561-571.

Deising, H., S. Heiler, M. Rauscher, H. Xu \& K. Mendgen. 1996. Cellular aspects of rust infection structure differentiation. Halaman 135-156 dalam: Nicole, M., V. GianinazziPearson, eds. Histology, Ultrastucture and Molecular Cytology of Plant - Microorganisms Interactions. Kluwer Academic Publishers, Amsterdam.

De Jong, J.C., B.J. McCormack, N. Smirnoff \& N.J. Talbot. 1997. Glycerol generates turgor in rice blast. Nature 389: 244-245.

De Lorenzo, G., R. Castoria, D. Bellincampi \& F. Cervone. 1997. Fungal invasion enzymes and their inhibition. Halaman 61-83 dalam: Carroll, G.C. \& P. Tudzynski, eds. The Mycota. Vol. V: Plant Relationship, Part A. Springer-Verlag, Berlin, Heidelberg \& New York.

Ebel, J. \& D. Scheel. 1997. Signals in host - parasite interactions. Halaman 85-106 dalam: Carroll, G.C. \& P. Tudzynski, eds. The Mycota. Vol. V: Plant Relationship, Part A. Springer-Verlag, Berlin, Heidelberg \& New York. 
Epstein, L. \& R.L. Nicholson. 1997. Adhesion of spores and hyphae to plant surfaces. Halaman 11-25 dalam: Carroll, G.C. \& P. Tudzynski, eds. The Mycota. Vol. V: Plant Relationship, Part A. Springer-Verlag, Berlin, Heidelberg \& New York.

Goodman, R.N. \& A.J. Novacky. 1994. The Hypersensitive Reaction in Plants to Pathogens. APS Press, St. Paul.

Govers, F., A. Drenth \& C.M.J. Pieterse. 1997. The potato late blight pathogen Phytophthora infestans and other pathogenic oomycota. Halaman 17-36 dalam: Carroll, G.C. \& P. Tudzynski, eds. The Mycota. Vol. V: Plant Relationship, Part B. Springer-Verlag, Berlin, Heidelberg \& New York.

Hahn, M., H. Deising, C. Struck \& K. Mendgen. 1997. Fungal morphogenesis and enzyme secretion during pathogenesis. Halaman 33-57 dalam: Hartleb, H., R. Heitefuss \& H. Hoppe, eds. Resistance of Crop Plants against Fungi. Gustav Fischer, Jena.

Heath, M.C. 1998. Apoptosis, programmed cell death and the hypersensitive response. Eur. J. Plant Pathol. 104: 117-124.

Howard, R.J. 1997. Breaching the outer barriers cuticle and cell wall penetration. Halaman 4360 dalam: Carroll, G.C. \& P. Tudzynski, eds. The Mycota. Vol. V: Plant Relationship, Part A. Springer-Verlag, Berlin, Heidelberg \& New York.

Jenks, M.A. \& E.N. Ashworth. 1999. Plant epicuticular waxes: Function, production and genetics. Hort. Rev. 23: 1-68.

Kobayashi, I., Y. Kobayashi \& A.R. Hardham. 1994. Dynamic reorganization of microtubules and microfilaments in flax cells during the resistance response to flax rust infection. Planta 195: 237-247.

Kobayashi, I., Y. Kobayashi, N. Yamaoka \& H. Kunoh. 1992. Recognition of a pathogen and a nonpathogen by barley coleoptile. III.
Responses of microtubules and actin filaments in barley coleoptile cells to penetration attempts. Can. J. Bot. 70: 1815-1823.

Kohmoto, K., U.S. Singh \& R.P. Singh. 1995. Pathogenesis and Host Specificity in Plant Diseases. Vol. II: Eukaryotes. Pergamon Press and Elsevier Science, Oxford.

Kolattukudy, P.E. \& M.S. Crawford. 1987. The role of polymer degrading enzymes in fungal pathogenesis. Halaman 75-95 dalam: Nishimura, S., V.P. Vance \& N. Doke, eds. Molecular Determinants of Plant Diseases Japan Scientific Society Press and SpringerVerlag, Tokyo, Berlin \& Heidelberg.

Köller, W. 1991. The plant cuticle. A barrier to be overcome by plant pathogens. Halaman 219246 dalam: Cole, G.T. \& H.C. Hoch, eds. The Fungal Spore and Disease Initiation in Plants and Animals. Plenum Press, New York \& London.

Köller, W., C. Yao, F. Trail \& D.M. Parker. 1995. Role of cutinase in the invasion of plants. Can. J. Bot. 73: 1109-1118.

Kombrink, E. \& I.E. Somssich. 1995. Defense responses of plants to pathogens. Adv. Bot. Res. Incorp. Adv. Plant Pathol. 21: 2-34.

Kubo, Y. \& I. Furusawa. 1991. Melanin biosynthesis: Prerequisite for successful invasion of the plant host by appresoria of Colletotrichum and Pyricularia. Halaman 205218 dalam: Cole, G.T. \& H.C. Hoch, eds. The Fungal Spore and Disease Initiation in Plants and Animals. Plenum Press, New York \& London.

Lebeda, A. 1984. A contribution to the general theory of host - parasite specificity. Phytopath. Z. 110: 226-234.

Lebeda, A., D. Jančová \& L. Luhová. 1999. Enzymes in fungal plant pathogenesis. Phyton. 39: 51-56. 
Lebeda, A. \& F.J. Schwinn. 1994. The downy mildews - an overview of recent research progress. Z. PflKrankh. PflSch. 101: 225-254.

Lucas, J.A., J.B.R. Hayter \& I.R. Crute. 1995. The downy mildews: Host specificity and pathogenesis. Halaman 217-238 dalam: Kohmoto, K., U.S. Singh \& R.P. Singh, eds. Pathogenesis and Host Specificity in Plant Diseases. Vol. II: Eukaryotes. Pergamon Press and Elsevier Science, Oxford.

Macko, V. 1981. Inhibitors and stimulants of spore germination and infection structure formation in fungi. Halaman 565-584 dalam: Turian, G. \& H.R. Hohl, eds. The Fungal Spore: Morphogenetic Control. Academic Press, New York.

Mansfield, J., M. Bennett, Ch. Bestwick \& A. WoodsTör. 1997. Phenotypic expression of gene-forgene interaction involving fungal and bacterial pathogens: variation from recognition to response. Halaman 265-291 dalam: Crute, I.R., E.B. Holub \& J.J. Burdon, eds. The Gene-forGene Relationship in Plant - Parasite Interactions. CAB International, Wallingford.

Mendgen, K. \& H. Deising. 1993. Infection structures of fungal plant pathogens - a cytological and physiological evaluation. New Phytol. 124: 193-213.

Mendgen, K., M. Hahn \& H. Deising. 1996. Morphogenesis and mechanisms of penetration by plant pathogenic fungi. Annu. Rev. Phytopathol. 34: 367-386.

Mims, C.W. \& E.A. Richardson. 1989.

Ultrastructure of appresorium development by basidiospore germlings of the rust fungus Gymnosporangium juniperi-virginianae. Protoplasma 148: 111-119.

Nicholson, R.I. 1996. Adhesion of fungal propagules. Halaman 117-134 dalam: Nicole, M., V. Gianinazzi-Pearson, eds. Histology, Ultrastucture and Molecular Cytology of Plant - Microorganisms Interactions. Kluwer Academic Publishers, Amsterdam.
Pascholati, S.F., H. Deising, B. Leite, D. Anderson \& R.L. Nicholson. 1993. Cutinase and nonspecific esterase activities in the conidial mucilage of Colletotrichum graminicola. Physiol. Mol. Plant Pathol. 42: 37-51.

Post-Beittenmiller, D. 1996. Biochemistry and molecular biology of wax production in plants. Annu. Rev. Plant Physiol. Plant Mol. Biol. 47: 405-430.

Smart, M.G. 1991. The plant cell wall as a barrier to fungal invasion. Halaman 47-66 dalam: Cole, G.T. \& H.C. Hoch, eds. The Fungal Spore and Disease Initiation in Plants and Animals. Plenum Press, New York \& London.

Somssich, I.E. \& K. Hahlbrock. 1998. Pathogen defence in plants - a paradigm of biological complexity. Trends Plant Sci. 3: 86-90.

Staples, R.C. \& H.C. Hoch. 1997. Physical and chemical cues for spore germination and appresorium formation by fungal pathogens. Halaman 27-40 dalam: Carroll, G.C. \& P. Tudzynski, eds. The Mycota. Vol. V: Plant Relationship, Part A. Springer-Verlag, Berlin, Heidelberg \& New York.

Struck, Ch., M. Hahn \& K. Mendgen. 1998. Infection structures of plant pathogenic fungi potential targets for plant disease control. $Z$. PflKrankh. PflSch. 105: 581-589.

Šutić, D.D. \& J.B. Sinclair. 1991. Anatomy and Physiology of Diseased Plants. CRC Press, Boston.

Templeton, M.D., K.R. Sharrock, J.K. Brown, R.N. Crowhurst \& E.H.A. Rikkering. 1994. The pectin lyase-encoding gene ( $p n l)$ family from Glomerella cingulata: characterization of pnlA and its expression in yeast. Gene 142: 141-146.

Valent, B. 1997. The rice blast fungus, Magnaporte grisea. Halaman 37-54 dalam: Carroll, G.C. \& P. Tudzynski, eds. The Mycota. Vol. V: Plant Relationship, Part B. Springer-Verlag, Berlin, Heidelberg \& New York.

Vidhyasekaran, P. 1997. Fungal pathogenesis in plants and crops. Molecular Biology and Host Defense Mechanisms. Marcel Dekker, New York. 
24 J. Hama dan Penyakit Tumbuhan Tropika 3 (1), 2003 
24 J. Hama dan Penyakit Tumbuhan Tropika, 3(1), 2003

A. Gafur: Aspek fisiologis dan biokimiawi infeksi cendawan patogen tumbuhan

Tabel 1. Beberapa spesies cendawan patogenik yang diketahui menghasilkan kutinase pada saat proses infeksi (dimodifikasi dari Köller (1991))

\begin{tabular}{|c|c|}
\hline Spesies cendawan & Spesies cendawan \\
\hline Alternaria alternata & Fusarium solani f. sp. phaseoli \\
\hline Botrytis cinerea & Fusarium solani f. sp. pisi \\
\hline \multicolumn{2}{|c|}{$\begin{array}{l}\text { Tabel 2. Beberapa enzim penghancur dinding sel (EPDS) yang dihasilkan cendawan } \\
\text { patogen (dimodifikasi dari De Lorenzo dkk. (1997) dan Hahn dkk. (1997)) }\end{array}$} \\
\hline Kelompok enzim & Contoh enzim \\
\hline Hidrolase & endopoligalakturonase, eksopoligalakturonase, ramnogalakturonase \\
\hline Liase & endopektat liase, eksopektat liase, endopektin liase, eksopektin liase \\
\hline Esterase & pektinmetilesterase \\
\hline Selulase & $\begin{array}{l}\text { endo- } \beta \text {-1,4-glukanase (karboksimetilselulase), ekso- } \beta \text {-1,4-glukanase, endo- } \beta \text {-1,4- } \\
\text { glukan sellobiohidrolase, } \beta \text {-glukosidase }\end{array}$ \\
\hline Depolimerase & $\begin{array}{l}\text { endo- } \alpha \text { - } 1,5 \text {-arabinose, } \alpha \text {-L-arabinofuranosidase, endo- } \beta \text { - } 1,4 \text {-silanase, } \beta \text {-silosidase, } \\
\text { endo- } \beta \text {-glukosidase, ekso- } \beta \text { - } 1,3 \text {-glukanase (laminarinase), ekso- } \beta-1,3-1,6 \text { - } \\
\text { glukanase (sinereanase), ekso- } \beta \text {-1,6-glukanase, } \beta \text {-1,4-galaktanase, } \\
\alpha \text {-galaktrosidase }\end{array}$ \\
\hline Protease & \\
\hline
\end{tabular}

